\title{
Use of caerulein with submaximal doses of secretin as a test of pancreatic function in man
}

\author{
A. RIBET ${ }^{1}$, R. TOURNUT, M. DUFFAUT, AND N. VAYSSE 2 \\ From the Groupe de Recherches de Biologie et Pathologie Digestive (INSERM U 151), Toulouse, France
}

SUMMARY The pancreatic exocrine secretory response to different combinations of the pancreozymin-like peptide caerulein and secretin was studied in 110 healthy control subjects and 32 patients with pancreatic disease. A combination of $0.5 \mathrm{CU} / \mathrm{kg}-\mathrm{h}$ secretin and $75 \mathrm{ng} / \mathrm{kg}-\mathrm{h}$ caerulein provided maximal or near-maximal stimulation of the secretion of both bicarbonate and pancreatic enzymes. The combination of stimulant peptides in the above doses was found to give excellent separation between the secretion of bicarbonate, lipase, and chymotrypsin of the control group and patients with chronic pancreatitis. A combination of caerulein and secretin represents a safe, reliable, and effective mean of stimulating pancreatic exocrine secretion for the purpose of testing pancreatic function.

Caerulein, a peptide containing seven aminoacids that is isolated from the skin of the Australian toad (Erspamer, 1970), has been proposed as a cheaper and purer substitute for cholecystokinin-pancreozymin in the clinical testing of pancreatic exocrine function (Bonfils et al., 1971; Fox, 1972; Ribet et al., 1972).

The purpose of the present study was to determine the optimal conditions for use of caerulein in the diagnosis of pancreatic disease by assessing the pancreatic capacity to secrete bicarbonate and particularly enzymes, by studying the effect of increasing doses of caerulein on pancreatic secretion in normal control subjects and in patients with different types of pancreatic disease.

\section{Methods}

The study involved 110 control adults without organic disease of the alimentary tract and with no history of alcoholism or diabetes mellitus. In addition, 32 patients with pancreatic disease were investigated, of whom 15 had chronic pancreatitis confirmed by radiological calcification of the pancreas or at laparotomy; 13 had recently (within three to five weeks) had acute pancreatitis, confirmed by hyperamylasaemia, and four had histologicallyproven carcinoma of the pancreas.

Intubation was carried out on the evening before the test. The tube was allowed to pass into the duo1Address: Groupe de Recherche de Pathologie Digestive, CHU Rangeuil L3, 31400 Toulouse, France.

sSupported by INSERM.

Received for publication 2 March 1976 denum during the night and positioned radiologically so that the aspiration holes were sited in the descending duodenum. A nasogastric tube was sited with its tip in the antrum.

Duodenal and gastric contents were aspirated manually with intermittent insufflation of air to maintain patency of the tubes.

Four stimulant schedules were employed:

1. Thirty-one control subjects received a continuous intravenous infusion of secretin $(0.5$ clinical units (CU)/kg-hour) that was given with caerulein for two periods of one hour, with an intervening period of 30 minutes without stimulation. Thus, each individual received two consecutive doses of caerulein, selected from $18,37 \cdot 5,75$, and $150 \mathrm{ng} / \mathrm{kg}-\mathrm{h}$, in addition to secretin.

2. Thirty control subjects received secretin (2 $\mathrm{CU} / \mathrm{kg}-\mathrm{h}$ ) for one hour.

3. Four control subjects underwent three tests each, in random order, comparing the response to secretin $(0.25 \mathrm{CU} / \mathrm{kg}-\mathrm{h})$, caerulein $(75 \mathrm{ng} / \mathrm{kg}-\mathrm{h})$, or secretin $(0.25 \mathrm{CU} / \mathrm{kg}-\mathrm{h})$ plus caerulein (75 $\mathrm{ng} / \mathrm{kg}-\mathrm{h}$ ).

4. The response to secretin $(0.5 \mathrm{CU} / \mathrm{kg}-\mathrm{h})$ plus caerulein $(75 \mathrm{ng} / \mathrm{kg}-\mathrm{h})$ was compared in 45 control subjects and 32 patients with pancreatic disease.

The secretin was purchased from the GIH Laboratory, Karolinska Institutet, Stockholm, Sweden. Caerulein was obtained from Farmitalia Research Laboratories, Milan, Italy.

Duodenal and gastric aspirates were collected in 10-minute batches and the volumes recorded. Bicarbonate concentration was measured by addition 
of excess acid and backtitrating with $0.1 \mathrm{M}$ sodium hydroxide to the previous $\mathrm{pH}$ of the batch; lipase activity was measured by the method of Sarles et al. (1963); amylase activity by the automatic method of Bourse et al. (1970); and chymotrypsin activity by the method of Figarella et al. (1965).

Bicarbonate and enzyme outputs were calculated for the secretion during the final $\mathbf{3 0}$ minutes of each period of stimulation. The means of each group of results were compared by Student's $t$ test. Because the distribution of the outputs of bicarbonate and enzymes was not Gaussian, the results were converted to logarithms to give a normal distribution. The means were then reconverted after statistical analysis.

\section{Results}

\section{BICARBONATE SECRETION}

The response to $2 \mathrm{CU} / \mathrm{kg}$-h secretion was significantly greater than the response to $0.25 \mathrm{CU} / \mathrm{kg}$-h secretin alone (Fig. 1). The addition of $75 \mathrm{ng} / \mathrm{kg}-\mathrm{h}$ caerulein increased the bicarbonate output to levels not significantly different from the response to $2 \mathrm{CU} / \mathrm{kg}-\mathrm{h}$ secretin alone (Fig. 1). The bicarbonate response to all doses of caerulein combined with $0.5 \mathrm{CU} / \mathrm{kg}-\mathrm{h}$ secretin was not significantly different from the response to $2 \mathrm{CU} / \mathrm{kg}-\mathrm{h}$ secretin $(\mathrm{P}>\mathbf{0} \cdot 1)$. There was no significant difference between the bicarbonate outputs to the different doses of caerulein $(P>0 \cdot 1)$ (Fig. 2).

The bicarbonate response to caerulein alone (75 $\mathbf{n g} / \mathbf{k g}-\mathrm{h}$ ) was very small (Fig. 1 ).

\section{ENZYME SECRETION}

The enzyme secretory response to caerulein alone ( $75 \mathrm{ng} / \mathrm{kg}-\mathrm{h}$ ) was greater than the enzyme secretory response to secretin $0.25 \mathrm{CU} / \mathrm{kg}-\mathrm{h}(\mathrm{P}<0.005$ for lipase, amylase, and chymotrypsin outputs).

The enzyme output in response to the combination of caerulein (75 ng/kg-h) plus secretin ( $0.25 \mathrm{CU} / \mathrm{kg}-\mathrm{h})$ was similar to the sum of the responses to the two stimulants given alone (Fig. 1) (P > 0.1).

The enzyme response to $75 \mathrm{ng} / \mathrm{kg}$-h caerulein plus $0.5 \mathrm{CU} / \mathrm{kg}$-h secretin was greater than the response to the secretin plus 18 or $37.5 \mathrm{ng} / \mathrm{kg}$-h caerulein (Fig. 2) but not statistically significant.

COMPARISON BETWEEN RESPONSES OF CONTROL SUBJECTS AND PATIENTS WITH PANCREATIC DISEASE

Bicarbonate response The bicarbonate secretory response to secretin $(0.5 \mathrm{CU} / \mathrm{kg}-\mathrm{h})$ plus caerulein (75 $\mathrm{ng} / \mathrm{kg}-\mathrm{h}$ ) in the control group was greater than that in all except three of the patients with chronic pancreatitis, but there was almost complete overlap between control results and the bicarbonate outputs
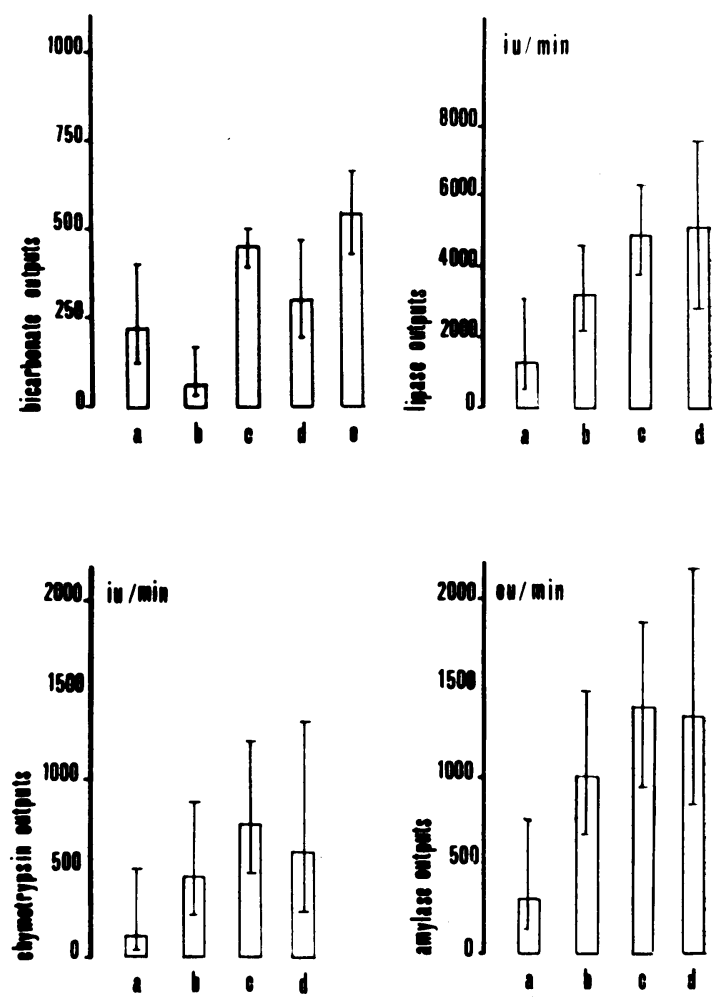

Fig. 1 Bicarbonate, lipase, amylase, and chymotrypsin outputs in response to: (a) secretin alone $0.25 \mathrm{CU} / \mathrm{kg}-\mathrm{h}$ $(n=4),(b)$ caerulein alone $75 n g / k g-h(n=4)$,

(c) secretin $0.25 \mathrm{CU} / \mathrm{kg}-\mathrm{h}$ associated with caerulein

$75 n g / k g-h(n=4),(d)$ as the sum of $(a)$ and $(b)(n=4)$, (e) secretin alone $2 \mathrm{CU} / \mathrm{kg}-\mathrm{h}(n=30)$. Each value indicates the mean and vertical bars represent standard deviation. $n=$ number of subjects. (iu: international unit, eu: enzymatic unit).

of the patients with acute pancreatitis and pancreatic cancer (Fig. 3).

Enzyme response The separation between chronic pancreatitis and the control group was similar for lipase and chymotrypsin, with only two patients with chronic pancreatitis in whom the results overlapped with those from the controls. The overlap with amylase output was considerably greater (Fig. 4).

The enzyme outputs of most patients recovering from acute pancreatitis and those with pancreatic carcinoma did not differ from the control.

Thus, complete overlap occurred between chronic pancreatitis, acute pancreatitis, and cancer.

No side effects were noted with any of the dose rates of secretin or caerulein, or combinations of these peptides. 


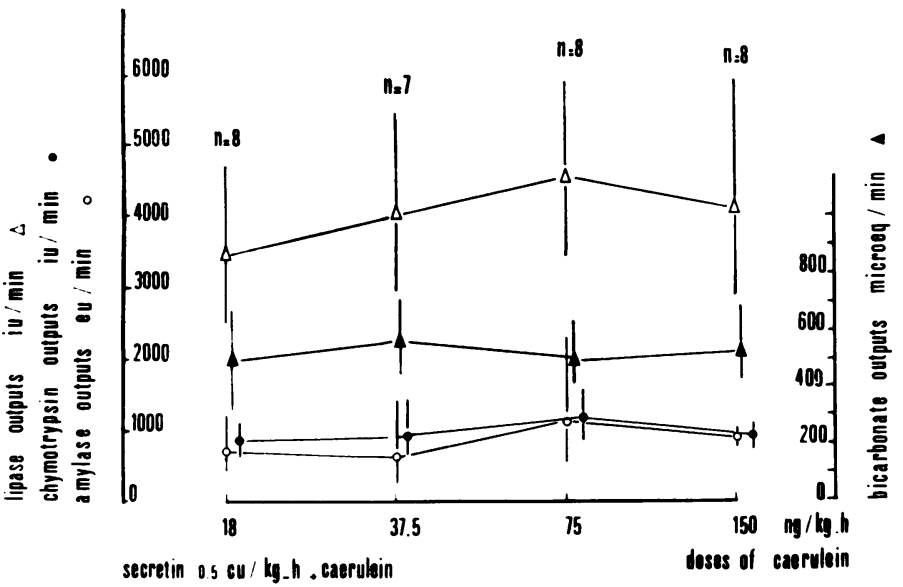

Fig. 2 Lipase $(\triangle)$, amylase $(O)$, chymotrypsin (O), and bicarbonate $(\Delta)$ outputs in response to secretin $(0.5$ CU/ $/ \mathrm{kg}-\mathrm{h})$ with graded doses of caerulein (ng/kg-h). Symbols refer to mean values, vertical bars represent standard deviation. $n=$ number of subjects. (iu: international unit, eu: enzymatic unit).

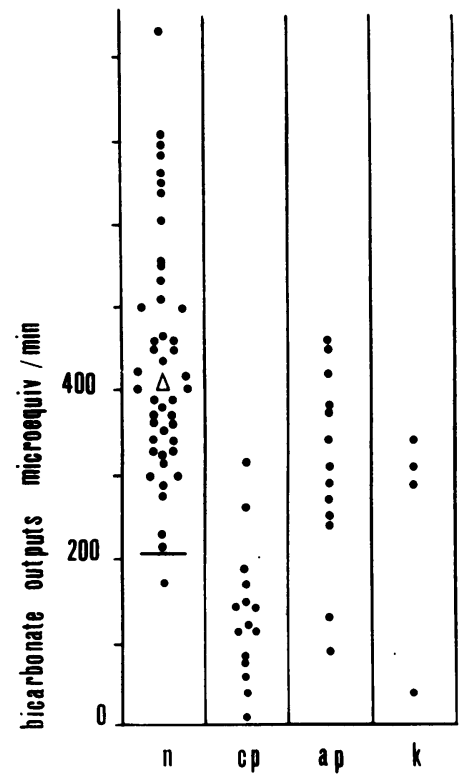

Fig. 3 Bicarbonate output in three groups of subjects. Controls (n), chronic pancreatitis with and without calcification (cp). Acute pancreatitis (ap). Carcinoma of the pancreas $(k) . \Delta$ is mean and the horizontal bar the minimum normal values.

\section{Discussion}

Rates of secretion of bicarbonate equivalent to the response to $2 \mathrm{CU} / \mathrm{kg}$-h secretin, which had previously been shown to produce maximal bicarbonate output (Ribet et al., 1971), were obtained with all doses of caerulein combined with a background dose of secretin $(0.5 \mathrm{CU} / \mathrm{kg}-\mathrm{h})$. However, the enzymesecretory response obtained with $75 \mathrm{ng} / \mathrm{kg}-\mathrm{h}$ caerulein was greater than the responses obtained with the two lower doses of caerulein; we therefore used that dose $(75 \mathrm{ng} / \mathrm{kg}-\mathrm{h})$ of caerulein combined with $0.5 \mathrm{CU} / \mathrm{kg}$-h secretin as a stimulant of pancreatic secretion both of bicarbonate and enzymes. This dose of caerulein was adequate to elicit a maximal enzymatic response as a higher dose resulted in an inhibition. This response was close to the maximal response elicited by cholecystokinin (Ribet et al., 1972). When the caerulein (75 $\mathrm{ng} / \mathrm{kg}-\mathrm{h})$ and cholecystokinin responses were compared on a molar basis the potency of caerulein was greater than that of cholecystokinin, confirming once again the greater potency of the smaller peptides (Debas and Grossman, 1973).

When we used this dose-combination of stimulants, excellent separation between control and chronic pancreatitis was achieved, taking both bicarbonate outputs and lipase and chymotrypsin secretion as discriminant criteria. The overlap between the outputs of amylase of the two groups precluded use of amylase secretion for diagnostic purposes. Similarly poor discrimination of amylase output between normal subjects and patients with pancreatic disease has been reported using CCK and secretin (Goldberg et al., 1972), probably because of its great variation coefficient and its smaller increase under stimulation in health and pancreatic disease (Minaire et al., 1973).

The discrimination between control subjects and patients with acute pancreatitis was unsatisfactory. The few patients with pancreatic carcinoma had a normal hydrelatic output with low values for the output of chymotrypsin and lipase. Thus, this result confirmed the value of the measurement of enzyme 

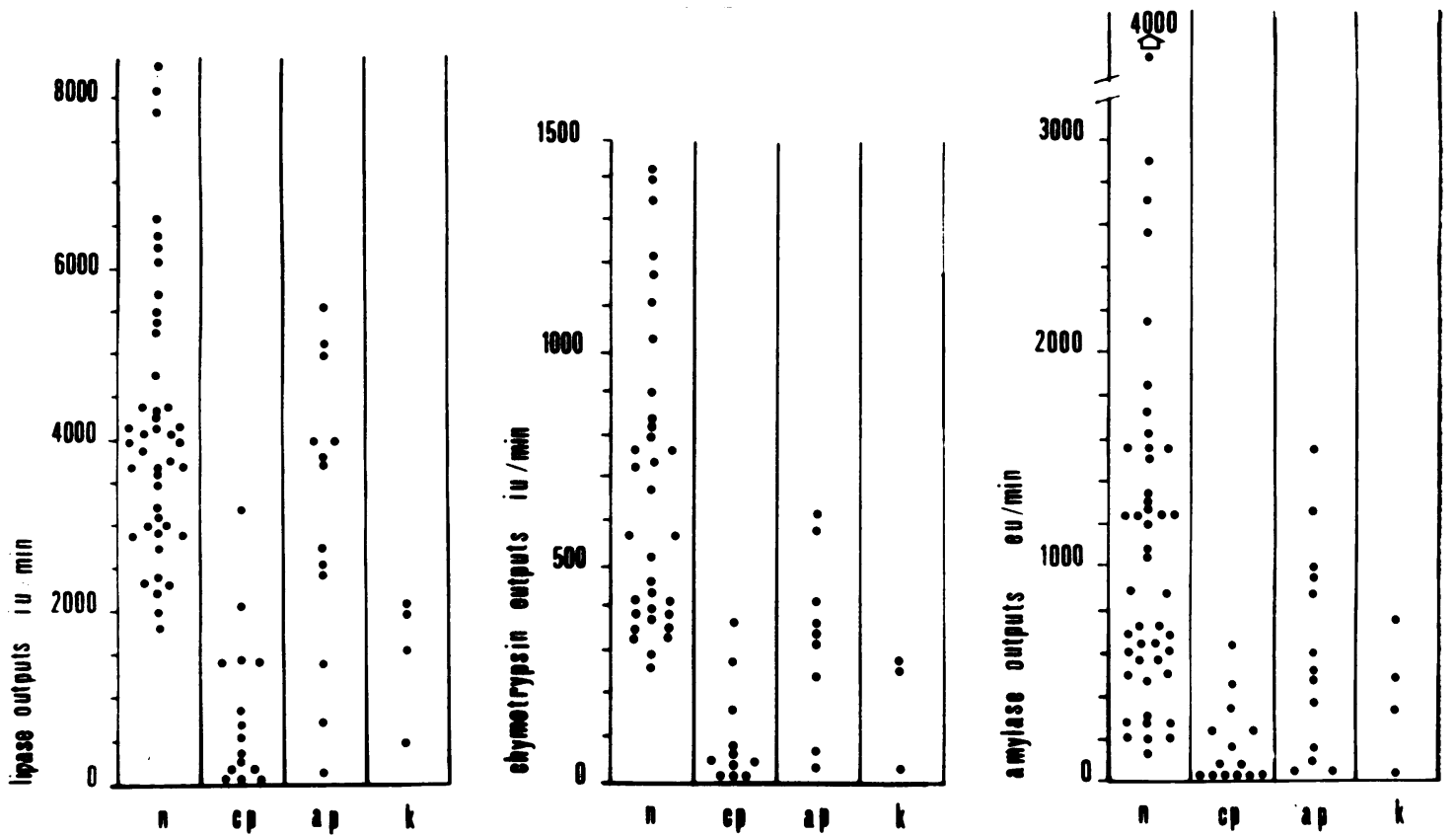

Fig. 4 Lipase, amylase, and chymotrypsin outputs. Same legend as Fig. 3. (iu: international unit, eu: enzymatic unit).

output in the study of pancreatic disease (Burton et al., 1960; Goldberg et al., 1972; Descos et al., 1974). While the pancreatic secretory response to a combination of caerulein and secretin cannot be used as sole criterion for the diagnosis of pancreatic carcinoma, the combination of peptides is a safe, reliable, and relatively inexpensive method of establishing the diagnosis of the pancreatic exocrine insufficiency caused by chronic pancreatitis.

We are indebted to Dr K. G. Wormsley for his helpful advice in the preparation of the manuscript. We are grateful to Mrs Varignon for her technical assistance and to Dr A. Ghione (Farmitalia Research Laboratories, Milan, Italy) for kindly supplying caerulein.

\section{References}

Bonfils, S., Gislon, J., and Junien, J. L. (1971). Premiers résultats de la caeruléine dans l'exploration fonctionnelle pancréatique chez l'homme. Acta Gastroenterologica Belgica, 34, 26-33.

Bourse, R., Vaysse, N., and Augier, D. (1970). Dosage automatique de l'amylase dans le liquide duodénal. Revue de Médecine, Toulouse, 6, 89-94.

Burton, P., Evans, D. G., Harper, A. A., Howat, H. T., Oleesky, S., Scott, J. E., and Varley, H. (1960). A test of pancreatic function in man based on the analysis of duodenal contents after administration of secretin and pancreozymin. Gut, 1, 111-124.

Debas, H. T., and Grossman, M. I. (1973). Pure cholecystokinin: pancreatic protein and bicarbonate response. Digestion, 9, 469-481.

Descos, L., Minaire, Y., Audigier, J. C., and Granthil, C. (1974). L'épreuve à la sécrétine-cholecystokinine dans les maladies du pancréas. Lyon Médical, 231, 1049-1053.

Erspamer, V. (1970). Progress report: caerulein, Gut, 11, 79-87.

Figarella, C., Taulier, J., and Sarles, H. (1965). Dosage de la chymotrypsine et de la trypsine dans le suc duodenal. Bulletin de la Société de Chimie Biologique, 47, 679-686.

Fox, A., Van der Hoeden, R., and Delcourt, A. (1972). Influence of caerulein on the exocrine function of the pancreas in man. Biologie et Gastro-enterologie, 5, 91-95.

Goldberg, D. M., Sale, J. K., Fawcett, A. N., and Wormsley, K. G. (1972). Trypsin and chymotrypsin as aids in the diagnosis of pancreatic disease. American Journal of Digestive Diseases, 17, 780-792.

Minaire, Y., Descos, L., Daly, J. P., Bererd, M. B., and Lambert, R. (1973). The interrelationships of pancreatic enzymes in health and diseases under cholecystokinin stimulation. Digestion, 9, 8-20.

Ribet, A., Pascal, J. P., and Vaysse, N. (1971). Etude comparative chez l'homme de l'activité de différentes sécrétines actuellement commercialisées. Acta Gastroenterologica Belgica, 34, 9-16.

Ribet, A., Duffaut, M., Vaysse, N., and Laval, J. (1972). Intérêt de la caeruléine en perfusion dans l'exploration fonctionnelle du pancréas exocrine. Archives Française des Maladies de l'Appareil Digestif, 61, 541-548.

Sarles, H., Taulier, J., and Figarella, C. (1963). Dosage de la lipase dans le suc duodenal. Revue Française d'Etudes Cliniques et Biologiques, 8, 706-707. 